\title{
Implementasi Analisis Keranjang Belanja Dengan Aturan Asosiasi Menggunakan Algoritma Apriori Pada Penjualan Suku Cadang Motor
}

\author{
Denny Haryanto ${ }^{1}$, Yetli Oslan ${ }^{2}$, Djoni Dwiyana ${ }^{3}$ \\ Program Studi Teknik Informatika, Universitas Kristen Duta Wacana \\ Jl. Dr. Wahidin 5-25, Yogyakarta 55224, Indonesia \\ Email: dknee29@gmail.com ${ }^{1}$
}

\begin{abstract}
Implementation of Shopping Cart Analysis with Assosiation Rules using Apriori Algorithm on Motorcycle Spare Parts Sales. At a distributor agent, most sales transactions are recorded in one information system. Data recorded, are only used for administrative purposes. Whereas these data contain information that can be processed for the other purposes. One is to find a special relationship between the products purchased at the same time. Based on these relationships, it is possible to do promotional items with bond patterns of the products. Consumers who buy the products will be interested to buy other products commonly bought. If consumers do not buy the products that exist in the pattern of sales of products, the distributor can offer products that exist in the pattern of sales of products. One of the combinations of pattern discovery algorithms products is apriori algorithm. The use of association methods in the search bond patterns of the products for the promotion of a product, is to minimize the promotion of products that have a low level of sales. By minimizing the promotional items that are not purchased, consumers will not interfere with the promotional items that do not have bond pattern, so that the promotional item will be more effective.
\end{abstract}

Keywords: Apriori Algorithm, Assosiation Rules, Sales Promotion, Sales Transacation, Bond Pattern

\begin{abstract}
Abstrak. Pada agen distributor, kebanyakan transaksi penjualan dicatat dalam satu sistem informasi. Data hasil pencatatan hanya digunakan untuk keperluan administrasi. Padahal data tersebut mengandung informasi yang dapat diproses untuk keperluan yang lebih luas. Salah satunya adalah untuk menemukan hubungan khusus antar produk yang dibeli bersamaan. Berdasarkan hubungan tersebut, dimungkinkan melakukan promosi barang dengan pola keterikatan barang tersebut. Konsumen yang membeli barang akan tertarik untuk membeli barang yang lain yang biasa dibelinya. Bila konsumen tidak membeli barang yang ada dalam pola penjualan barang, distributor dapat menawarkan barang yang ada dalam pola penjualan barang. Salah satu algoritma penemuan kombinasi pola barang adalah algoritma apriori. Penggunaan metode asosiasi dalam pencarian pola keterikatan untuk promosi produk, diharapkan dapat meminimalkan promosi barang yang mempunyai tingkat penjualan rendah. Dengan meminimalkan promosi barang yang tidak terbeli, konsumen tidak akan terganggu dengan promosi barang yang tidak mempunyai pola keterikatan, sehingga promosi akan lebih efektif.
\end{abstract}

Kata Kunci: Algioritma Apriori, Aturan Asosiasi, Promosi Penjualan, Transaksi Penjualan, Pola Keterikatan

\section{Pendahuluan}

\subsection{Latar Belakang}


Saat ini terdapat agen-agen distributor suku cadang motor yang menawarkan barang dagangannya kepada toko-toko atau bengkel motor. Suku cadang yang ditawarkanpun beraneka ragam, mulai dari suku cadang modifikasi hingga suku cadang imitasi. Dengan persaingan harga produk para agen distributor suku cadang motor mulai bersaing. Daerah jangkauan menjadi kelebihan bagi para distributor untuk melebarkan daerah pemasarannya.

Penawaran barang-barang mulai dilakukan di tiap konsumennya tanpa pertimbanganpertimbangan apakah barang tersebut akan terbeli atau tidak. Sering barang yang ditawarkan tidak terjual dan menjadi kelemahan bagi para agen tersebut, karena konsumen merasa terganggu dengan penawaran produk-produk yang tidak sesuai dengan kebutuhannya. Melalui pertimbangan ini tiap distributor perlu untuk melakukan manajemen kebutuhan konsumennya. Pendekatan ini dipakai untuk memelihara hubungan konsumen dan distributor. Salah satu faktor penting dalam melakukan hubungan ini adalah memberikan penawaran produk yang tepat untuk tiap-tiap konsumennya.

Salah satu cara untuk melakukan penawaran produk yang tepat dengan melakukan analisa terhadap data penjualan yang sudah ada. Data-data penjualan dianalisa untuk mencari pola keterikatan untuk tiap-tiap barang. Setelah pola keterikatan tiap barang didapat, lalu dicari tingkat keterikatannya. Tingkat keterikatan dari tiap barang dapat berbeda-beda tergantung dari data yang ada. Jika analisis ini dilakukan secara manual, tentu membutuhkan waktu dan tenaga yang cukup banyak, apalagi data yang dianalisa bukan saja data satu tahun, tetapi data yang dikumpul dari beberapa tahun. Selain itu, analisis secara manual juga akan menghasilkan hasil analisa yang kurang tepat.

\subsection{Rumusan Masalah}

Penawaran suatu produk kepada konsumen biasanya dilakuakan dengan pertimbangan tingkat produk yang terlaris atau tujuan tertentu. Misalnya : ingin menjual produk yang memiliki jumlah stok terbanyak. Bila sistem penawaran ini dilakukan untuk penjual yang memiliki macam barang yang sangat banyak dan tingkat kelarisan tertentu seperti pada agen distributor maka, sistem ini tidak akan mampu untuk menanganinya. Salah satu pertimbangan penawaran yang dapat digunakan adalah dengan mencari pola keterkaitan antar barang. Keterkaitan ini dapat dilihat dari komposisi barang yang sering dibeli bersamaan.

Pada kasus ini akan dilakukan analisis dengan menggunakan metode market basket analysis terhadap data transaksi penjualan agen distributor suku cadang motor untuk menentukan suatu aturan yang digunakan dalam penawaran suatu barang berdasar dari pola transaksi penjualan.

Selain itu juga digunakan metode association dengan algoritma apriori untuk menentukan pola keterkaitan barang. Hasil yang didapat dari metode market basket analysis akan diujikan dengan metode association untuk mendapatkan penawaran produk yang tepat yang sering dibeli secara bersamaan dan akan digunakan untuk penawaran barang dengan nilai kepercayaan yang diinginkan. Sehingga dengan implementasi metode market basket analysis diharapkan dapat meningkatkan tingkat penjualan barang pada agen distributor suku cadang motor ini.

\subsection{Batasan Masalah}

Agar pembahasan menjadi terfokus, maka dibuat batasan masalah sebagai berikut: (1) Data yang dipakai dalam studi kasus hanya data pada tabel transaksi penjualan dalam periode tahun 2001 sampai dengan tahun 2003, dan data tabel nama barang. (2) Parameter yang digunakan dalam tabel transaksi adalah no.transaksi dan no.index barang. (3) Penerapan metode association dan Algoritma Apriori untuk menemukan penawaran pola barang dari tabel pertimbangan, dan nilai confidence dari pola tersebut. 


\subsection{Maksud dan Tujuan}

Maksud dan tujuan dari penelitian ini adalah: (1) Mengetahui hubungan antar barang dan meningkatkan tingkat penjualan produk suku cadang motor. (2) Membantu pihak distributor, dalam melakukan penawaran produknya melalui analisa keranjang belanja dengan pendekatan association rules secara cepat dan tepat.

\section{Tinjauan Pustaka}

\subsection{Pengertian Data Warehouse}

Data warehouse merupakan sebuah tempat penyimpanan duplikasi data transaksi yang dibangun terstruktur secara khusus untuk di-query, dianalisis dan proses pembuatan laporan (Marakas, 2003). Dari definisi data warehouse dapat digambarkan secara jelas ke dalam beberapa fakta.

Pertama data warehouse merupakan sebuah database yang berisi duplikasi data transaksi. Hal ini menunjukkan bahwa data warehouse organisasi dan database maupun sistem pemroses data suatu organisasi adalah terpisah dan tidak terhubung sama sekali. Selanjutnya, karena data warehouse merupakan tempat penyimpanan dari duplikasi data transaksi, maka kecenderungan yang terjadi adalah data yang sudah dimasukkan kedalam data warehouse tidak akan diubah lagi. Hal ini menunjukkan bahwa data warehouse adalah bersifat tetap, lebih jauh lagi bahwa data warehouse tidak akan semakin mengecil ukurannya, namun akan semakin bertambah besar proporsinya.

Fakta kedua dari definisi yang telah disebutkan diatas adalah tempat penyimpanan duplikasi data transaksi yang dibangun terstruktur secara khusus. Hal ini menunjukkan selain harus sama dengan data asli, juga harus disesuaikan dengan struktur tertentu yang spesifik sehingga data dari berbagai sumber yang berbeda dapat ditempatkan ke dalam data warehouse.

Fakta terakhir yang kita dapat defini data warehouse di atas adalah memiliki kegunaan untuk di-query, dianalisis dan proses pembuatan laporan. Data warehouse menjadi tempat penyimpanan sentral untuk semua data transaksional organisasi yang dianggap berguna untuk suatu penelusuran terhadap adanya relasi yang baru, tren, maupun nilai-nilai lainnya yang tersembunyi. Selain itu data warehouse juga menjadi titik pusat utama untuk semua anggota organisasi untuk mencari dan memajukan tingkat pengetahuan mereka akan bisnis yang sedang dijalani.

\subsection{Model Konseptual Data Warehouse}

Model data entity-relationship adalah model yang paling sering digunakan untuk mendesain basis data yang mempunyai relasi (relational database), di mana skema basis data terdiri dari beberapa entity dan sejumlah relasi di antara tabel-tabel tersebut. Pada data warehouse, model yang paling populer adalah model multidimensional. Beberapa model dapat menggunakan format dari 'Star Schema', 'Snowflake Schema' ataupun 'Fact Constellation Schema' (Han, 2001).

\subsection{Pengertian Data Marts}

Data Marts merupakan bagian dari data warehouse yang lebih kecil dan dibangun dengan tujuan yang lebih spesifik (Marakas, 2003). Di dalam perusahaan data marts digunakan oleh instansi tertentu dengan kebutuhan analisis data yang lebih spesifik. 


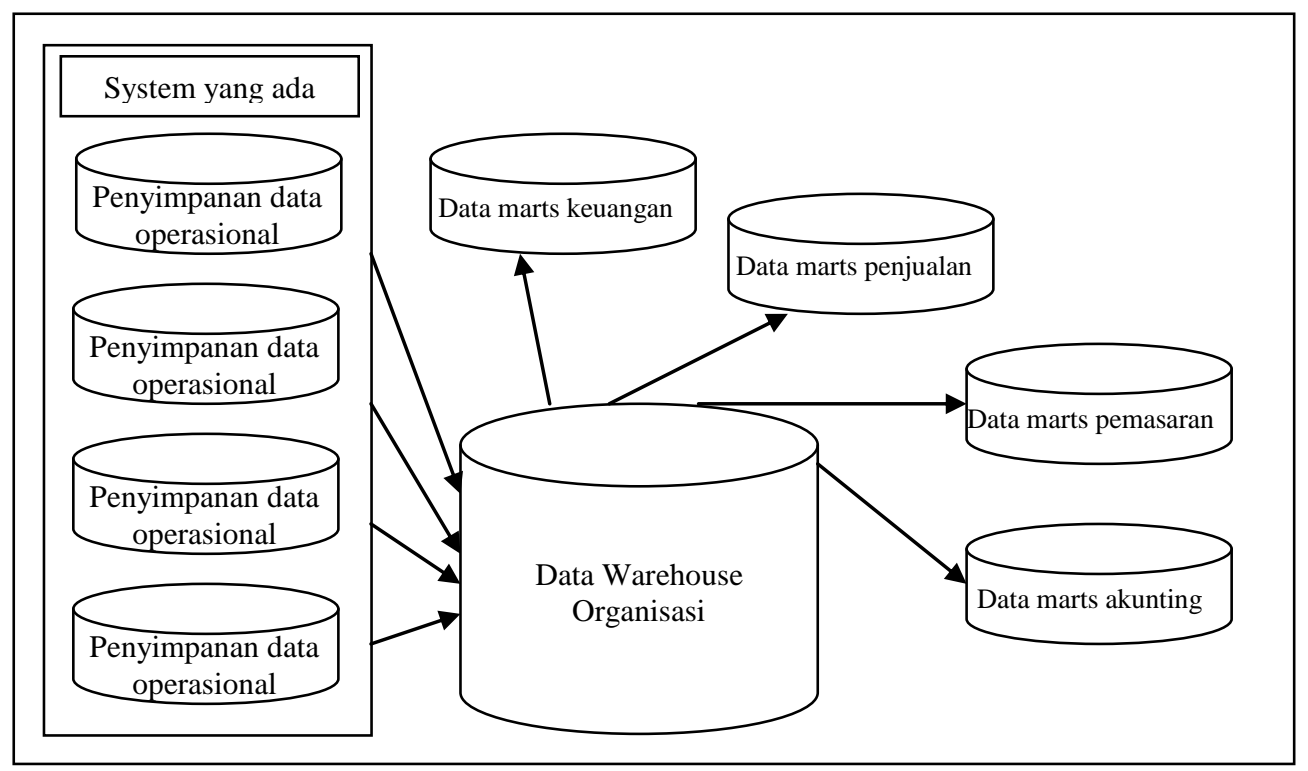

Gambar 1. Hubungan data warehouse dan data marts

Data marts dibangun dengan aturan-aturan utama sebagai berikut (Ibid): (1) Data marts mencerminkan dari aturan bisnis dari sebuah fungsi khusus atau instansi yang bukan merupakan perusahaan secara keseluruhan, diterapkan dalam menarik informasi pendukung keputusan yang stategis. (2) Data yang dikandung data marts diambil dari sumber yang relatif stabil, bersih dan terintegrasi, sehingga dalam pemakaiannya data masukan ke dalam data mart tidak perlu untuk diintegrasikan maupun dibersihkan. (3) Data marts terdiri dari kumpulan tabel yang didesain untuk akses langsung oleh pemakai yang akan menganalisis data tersebut dengan beberapa parameter yang telah ditentukan sebelumnya. Karakteristik data marts ini membutuhkan suatu struktur yang mendukung analisis yang dapat diterapkan dengan mudah dan intuitif, dengan parameter-parameter dan hirarkinya. (4) Karena merupakan kumpulan tabel yang di desain untuk mendukung adanya pengelompokan data didalamnya, maka sebagian besar query akan dilakukan dengan beberapa pengelompokan dari dimensi datanya. (5) Data marts bukan merupakan sumber data yang digunakan untuk analisis statis yang tradisional maupun data mining. Dengan mengabaikan beberapa kebutuhan yang dibutuhkan dalam analisis statis maupun data mining maka memungkinkan data disimpan selama tidak melanggar aturan yang ditetapkan dalam suatu relasi.

\subsection{Pengertian Market Basket Analysis}

Market basket analysis adalah suatu teknik matematis yang dipakai secara umum oleh profesional pemasaran untuk mengungkap persamaan atau hubungan keterikatan antar produk maupun antar kumpulan produk (Redlon, 2002). Market basket analysis menentukan produk apa yang dibeli bersamaan. Setelah perusahaan mengetahui ketika satu produk akan dibeli bersamaan dengan produk lainnya, maka perusahaan dapat memasarkan dan menjadikan pembeli produk tertentu sebagai target prospek untuk produk lainnya. Hal ini akan meningkatkan tingkat efektivitas pemasaran dan taktik penjualan dengan menggunakan data konsumen yang tersedia (Marakas, 2003).

\subsection{Keuntungan Penggunaan Market Basket Analysis}

Bagi pedagang eceran, mengetahui produk yang sering dibeli bersamaan memberikan keuntungan tersendiri di dalam dunia perdagangan dengan perilaku konsumennya yang sangat kompetitif. Efek yang sangat nyata dari market basket analysis adalah adanya peningkatan penjualan bagi pedagang eceran dengan mengatur barang-barang yang sering dibeli bersamaan 
di tempat yang berdekatan. Strategi penempatan ini meningkatkan pembelian dan membantu memastikan bahwa pembeli yang membeli suatu barang tidak akan lupa untuk membeli barang lain hanya karena mereka tidak melihatnya. Dan sebagai tambahannya konsumen juga akan merasakan kenyamanan karena barang yang akan dibeli bersamaan ditempatkan berdekatan, yang akan meningkatkan nilai kepuasan pembeli.

Di luar lingkungan toko, market basket analysis juga menyediakan keuntungan yang berbeda. Untuk distributor, akan lebih baik dalam memasarkan barang kepada toko yang ada, yang telah membeli barang dan tercatat datanya. Market basket analysis memungkinkan distributor menghubungi konsumen utamanya tentang informasi produk yang juga telah terbukti terjual dengan baik bersamaan produk yang sering mereka beli. Selain itu, dalam penawaran barang kepada konsumen dapat disertakan beberapa barang yang dijual bersamaan dengan potongan harga.

\subsection{Pengertian Association Rules}

Association rules adalah teknik dalam menemukan pola pemunculan, pola pengumpulan, pola pertalian, pola struktur sebab akibat dari kumpulan atau obyek dalam basis data transaksi, relasi basis data, dan informasi pendukung lainnya (Sander, 2003). Pemodelan lokal merupakan salah satu metode yang dipakai dalam data mining : Dependency Modeling. Tujuan utama association rules adalah untuk menemukan suatu hubungan yang penting dan menarik dari kumpulan data dimana kehadiran beberapa barang dalam transaksi akan mempengaruhi kehadiran barang lain dalam transaksi yang sama (Shyu, 2002). Dengan I adalah kumpulan produk yang terdapat dalam transaksi, setiap transaksi $\mathrm{T}$ adalah kumpulan barang yang memenuhi $\mathrm{T} \subseteq \mathrm{I}$. Dari setiap transaksi $\mathrm{T}$ dikatakan mengandung produk $\mathrm{X}$ jika dan hanya jika $\mathrm{X} \subseteq \mathrm{T}$. Secara tidak langsung ketentuan tersebut mempengaruhi $\mathrm{X} \Rightarrow \mathrm{Y}$, dimana $\mathrm{X} \subseteq \mathrm{I}$ dan $\mathrm{Y} \subseteq \mathrm{I}$, dan $\mathrm{X} \cap \mathrm{Y}=\varnothing$. Aturan $\mathrm{X} \Rightarrow \mathrm{Y}$ dalam association rules menerangkan asosiasi antara $\mathrm{X}$ dan $Y$.

Dalam pemakaian association rules, aturan yang digunakan bersifat satu arah, untuk membedakannya dipakai istilah analysis unit dan associated unit. Analysis unit merupakan suatu produk X yang menjadi pokok aturan dan produk Y yang terpengaruhi oleh pokok aturan adalah associated unit. Untuk membuat pemakaian association rules, yang merupakan turunan dari aturan prediksi dari market basket analysis, menjadi efektif dipakai aturan : support, confidence, dan lift.

\subsection{Algoritma Apriori}

Algoritma apriori digunakan untuk menemukan association rules yang memenuhi batas nilai support dan confidence. Cara kerja apriori adalah dengan menganalisa kumpulan barang yang dibeli bersamaan pada beberapa transaksi. penghitung kumpulan pola data yang muncul di dalam database melalui beberapa iterasi atau perulangan. Iterasi $i$ menghitung semua kumpulan data $i$ ( kumpulan data yang mengandung elemen $i$ ) yang sering muncul. Setiap iterasi terdiri dari dua langkah yaitu candidate generation ( penentuan kandidat) dan candidate counting and selection ( pemilihan serta penghitungan kandidat) (Kantardzic, 2003).

Dalam tahap pertama iterasi, dalam kumpulan data yang ditentukan mengandung semua elemen $i$. Dalam tahap penghitungan, algoritma Apriori menghitung nilai support terhadap tiap elemen dalam database. Hanya kumpulan data $i$ dengan batas minimal yang telah ditentukan akan dimasukkan ke dalam kandidat barang yang sering muncul.

Pencarian pola kombinasi barang dalam apriori tidak dapat secara langsung menggabungkan elemen $i$ dengan seluruh jenis barang yang diterima. Bila pencarian kombinasi barang dilakukan secara langsung maka waktu yang dibutuhkan untuk mencari kombinasi barang akan lebih lama. Cara yang dilakukan dalam algoritma apriori ini adalah dengan melakukan self-joining iterasi sebelumnya (Sander, 2004). Berikut adalah contoh self-joning 
tabel.

Isi tabel pada iterasi ke 3 : (1 $\left.\begin{array}{lll}1 & 3\end{array}\right),\left(\begin{array}{lll}1 & 2 & 4\end{array}\right),\left(\begin{array}{lll}1 & 3 & 4\end{array}\right),\left(\begin{array}{lll}1 & 3 & 5\end{array}\right),\left(\begin{array}{lll}2 & 3 & 4\end{array}\right)$

Dengan menggunakan kombinasi biasa akan menghasilkan tabel kombinasi : (1 234 ), (1 23 5), (1 $\left.2 \begin{array}{lll} & 4 & 5\end{array}\right),\left(\begin{array}{llll}1 & 3 & 4 & 5\end{array}\right),\left(\begin{array}{llll}2 & 3 & 4 & 5\end{array}\right)$

Dengan menggunakan self-join akan menghasilkan tabel kombinasi : (1 2334$),\left(\begin{array}{lll}1 & 3 & 4\end{array}\right)$

Gambaran langkah dalam self join dapat dilihat pada gambar 2.

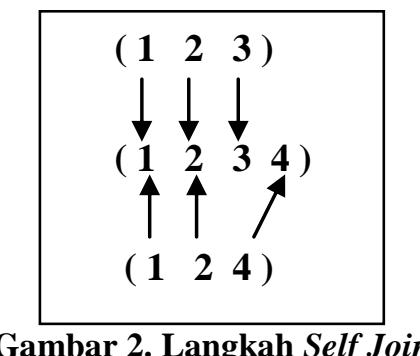

Dari keterangan self-join tersebut, maka kombinasi yang terbuang :

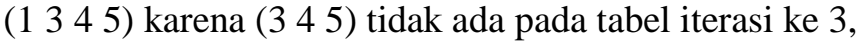

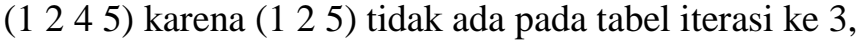

(2 $\left.34 \begin{array}{ll}5\end{array}\right)$ karena (2 3 5) tidak ada pada tabel iterasi ke 3.

\section{Metodologi Penelitian}

\subsection{Perancangan Skema}

\subsubsection{Proses Analisis Association}

Proses analisis association dilakukan untuk mendapatkan hubungan keterikatan antar tiap barang yang ada. Proses ini dilakukan pada flat tabel penjualan untuk melihat keterikatan barang-barang yang dibeli secara bersamaan. Sebelum tabel flat penjualan ada, maka dibuat tabel flat penjualan dari data penjualan tahun tertentu.

\subsubsection{Proses Penawaran Dengan Market Basket Analysis}

Setelah proses analisis association selesai dan ditampung pada sebuah tabel penawaran. Tabel penawaran ini dibutuhkan untuk mencari barang-barang yang akan ditawarkan melalui proses Market Basket analysis ini. Setelah proses pencarian penawaran selesai maka penawaran barang akan ditampilkan dan digunakan sebagai pertimbangan barang yang akan dijadikan penawaran kepada konsumen.

\subsection{Multidimensional Models}

Pada data warehose ini mempergunakan model multidimensional, sedangkan format atau skema dari data warehouse ini menggunakan skema snowflakes. Skema snowflakes adalah variasi lain dari model skema bintang (stars schema), di mana beberapa tabel dimensi telah ternormalisasi, dan terdapat beberapa data yang terpisah menjadi beberapa tabel yang baru. Keuntungan dari format multidimensional, snowflakes schema adalah tabel yang telah ternormalisasi untuk mengurangi redundansi data.

Pada penerapan dalam data mining tidak seluruh data dalam data warehouse digunakan. Pemilihan data apa saja yang digunakan berdasarkan pada kebutuhan sistem yang akan dibuat. Karena analisis yang dilakukan adalah relasi barang yang terjual secara bersamaan maka sudut pandang yang dipakai adalah barang-barang yang terjual secara bersamaan tanpa memperhatikan siapa yang membeli atau yang lainnya. 


\section{Fact Table Transaksi Penjualan}

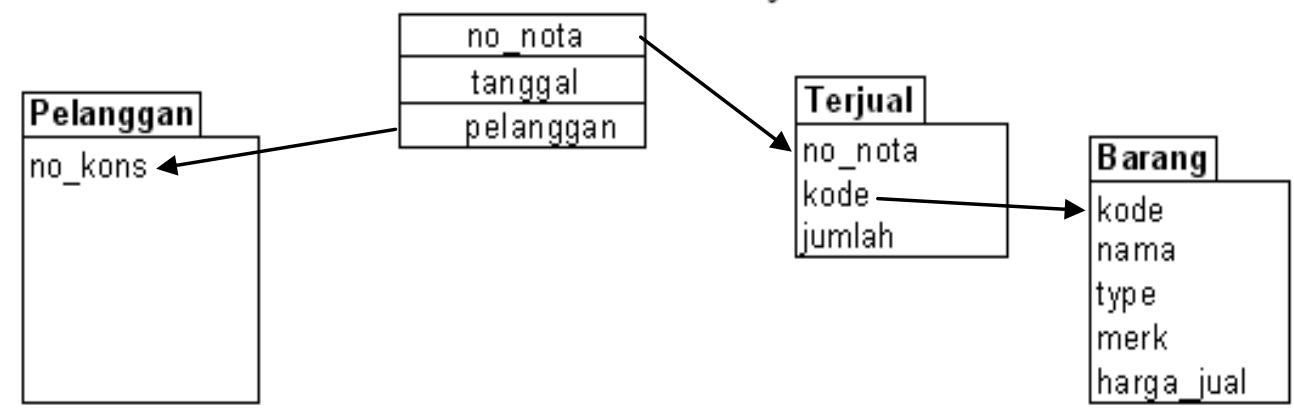

Gambar 3. Snowflakes Schema

\subsection{Denormalisasi Tabel}

Dari tabel terjual maka dibuat sebuah tabel flat transaksi yang merupakan denormalisasi dari tabel terjual tersebut. Adapun contoh dari denormalisasi tersebut dapat dilihat di tabel 1.

Tabel 1. Tabel contoh flat_transaksi

\begin{tabular}{cccccc}
\hline TWA07213 & TWA07503 & TWA07115 & TWA07306 & TWA07120 & $\begin{array}{c}\text { s/d nomor barang } \\
\text { terakhir }\end{array}$ \\
\hline 1 & 1 & 1 & 0 & 0 \\
\hline 1 & 1 & 0 & 0 & 0 \\
\hline 1 & 1 & 1 & 1 & 1 \\
\hline 1 & 0 & 0 & 1 & 0 \\
\hline
\end{tabular}

\subsection{Kamus Data}

Untuk memberikan penjelasan tentang field-field yang digunakan dalam setiap tabel yang dibuat dalam sistem ini dapat dilihat pada tabel dibawah ini. Tabel yang digunakan oleh sistem terdiri dari 2 macam yaitu : (1) Tabel yang digunakan saat transaksional yang terdiri dari tabel transaksi_jual, tabel penjualan, tabel konsumen, tabel temp_penjualan, dan tabel barang. (2) Tabel yang digunakan saat pencarian penawaran yaitu tabel analisa, tabel tem_iterasi_n(tergantung dari jumlah kombinasi yang ada), tabel pertimbangan, tabel temp_barang, tabel iterasi_n (tergantung dari jumlah interaksi yang terjadi), tabel combinasi_beli_n, tabel penawaran, dan tabel barang_cetak.

\subsection{Perancangan Input dan Output}

Sistem yang dibuat terdiri dari dua bagian yang terpisah berdasarkan fungsinya, Sistem yang pertama digunakan untuk mengambil data transaksi penjualan. Dalam sistem ini inputannya adalah database yang ingin dgunakan untuk analisis association, karena data yang tersedia dipisah-pisah pertahun maka dipilih data apa saja yang ingin diinputkan (dalam contoh kasus ini data transaksi jual hanya disediakan tahun 2001, tahun 2002, dan tahun 2003). Sistem ini akan merubah dari database asli ke flat table yang digunakan untuk proses analisa association. Pada sistem ini disediakan fasilitas untuk membatasi inputan nilai support minimal yang diperbolehkan.

Sistem yang kedua adalah transaksi penjualan dan penawaran, sub sistem ini menangani proses penjualan barang, dan penawaran untuk barang-barang yang ada. Inputan dari sistem ini adalah penjualan barang-barang dan nilai support minimal (sesuai dengan batasan yang sudah ditetapkan pada sistem sebelumnya) nilai minimal tidak dapat kurang dari nilai minimal yang ditetapkan dan tidak dapat melebihi nilai maksimal yang ditetapkan. Hasil yang dikeluarkan 
adalah penawaran barang-barang dan nilai confidence untuk tiap barang dalam bentuk teks dan grafik yang mewakili nilai support tiap barang.

\subsubsection{Perancangan Input pada Sistem Input Data Pertimbangan}

Sistem input data pertimbangan digunakan untuk memasukan data transaksi penjualan yang lampau untuk digunakan sebagai faktor pertimbangan penawaran barang. Pada prosesnya sistem ini hanya mengambil backup database yang diinginkan sebagai pertimbangan penawaran. Setelah data transaksi selama beberapa tahun diambil dan diubah ke bentuk baru (menggunakan SQL SERVER), lalu dilakukan perubahan bentuk tabel relasional menjadi bentuk flat table dengan hanya mengambil kode_barang yang dibeli secara bersamaan.

Pada sistem input data pertimbangan memiliki 2 fungsi. Selain mengambil data transaksi jual yang digunakan untuk pertimbangan penawaran dan merubah menjadi flat table, sistem ini juga mempunyai fungsi untuk menetapkan batas atas dan bawah dari nilai minimal support yang diijinkan dalam proses penawaran.

\section{Pengujian dan Pembahasan}

Sesuai dengan perancangan skema yang telah dilakukan maka implementasi sistem yang dilakukan akan terbagi menjadi dua sub sistem yang terpisah secara fungsinya. Dimana fungsi sistem yang pertama akan menangani proses penginputan data analisa, dan batasan support yang diperbolehkan. Sedangkan fungsi sistem yang kedua akan menangani input transaksi penjualan serta penawaran barang.

\subsection{Menu Login}

Karena terdapat 2 sub sistem maka tampilan awal dari sistem ini adalah menu. Dalam tampilan menu user dapat memilih hak akses dalam menggunakan sistem. Hak akses yang ada dalam sistem ini adalah database admin dan marketing. Perbedaan hak akses akan mempengaruhi sub sistem yang akan digunakan. Pada database admin, sistem yang akan ditangani adalah sistem preprosesing yang meliputi inputan database yang dijadikan pertimbangan dan penetapan batasan nilai support. Dan bila pada marketing sistem yang akan ditangani adalah sistem penawaran yang meliputi inputan transaksi penjualan, dan penawaran produk.

\subsection{Sub Sistem Persiapan Data Pertimbangan}

Dalam sub sistem ini terdapat fasilitas untuk menginputkan data yang akan diubah menjadi flat table. Karena backup tabel penjualan yang digunakan dalam bentuk tabel visual fox pro maka perlu dilakukan pengambilan isi tabel dan mentransfernya ke tabel SQL Server 2000. Untuk menambah data pertimbangan (beberapa tahun) dapat mengulang proses pencarian dan peng-copy-an data, karena tabel yang dimasukan pertahun maka proses dapat diulang sesuai keinginan user. Selain perubahan tabel pada form set data pertimbangan juga terdapat fasilitas untuk menyimpan batasan nilai minimal support.

\subsection{Sub Sistem Penjualan dan Penawaran}

Sub sistem ini merupakan inti proses dari penawaran barang. Fasilitas yang ada pada sub sistem ini adalah pencatatan transaksi penjualan, melihat data barang, pencarian penawaran barang dan mencetak penawaran barang tersebut.

Sebelum mencari penawaran barang langkah awal adalah mengisi transaksi penjualan, dengan cara masuk dalam form transaksi penjualan. Untuk melakukan transaksi penjualan, pertama user harus menginputkan konsumen dengan memilih konsumen dari form data 
konsumen. Pada form konsumen, user dapat memilih 1 konsumen yang dicatat penjualannya. Langkah selanjutnya dalam mencatat transaksi penjualan adalah memilih barang yang terjual pada frame nomer nota, sehingga user dapat mencari barang yang terjual dari form list barang. Setelah proses pemilihan barang selesai langkah selanjutnya adalah menginputkan jumlah barang yang akan terjual. Dari pembelian barang tersebut, akan disimpan sementara di tabel temp_penjualan. Langkah pencarian barang dan memasukan ke tabel temp_penjualan diulang hingga transaksi penjualan untuk 1 nomer nota selesai.

Proses penawaran dilakukan pada form penawaran seperti terlihat pada gambar 4. Pada proses penawaran penjualan yang dapat dilakukan proses penawaran adalah transaksi penjualan yang sudah tersimpan pada program ini. Langkah pertama adalah user menginputkan nomer nota penjualan dari form transaksi. Langkah kedua adalah menginputkan nilai minimal support dan nilai minimal confidence sebagai batas bawah penawaran barang tersebut. Setelah itu maka proses pencarian penawaran barang dapat dilakukan.

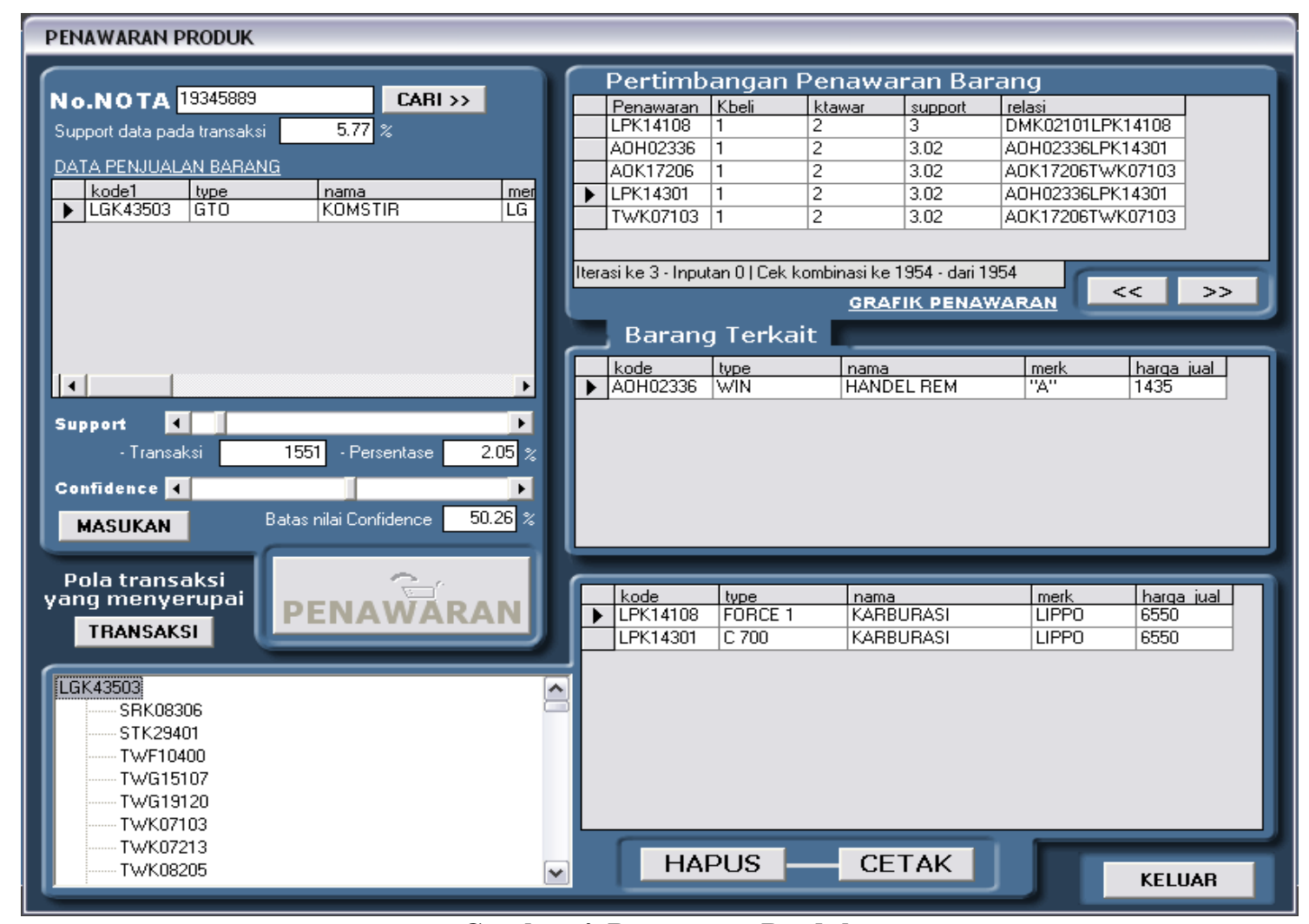

Gambar 4. Penawaran Produk

Algoritma selft join yang digunakan untuk menemukan candidat key dalam apriori adalah sebagai berikut.

insert into $C k$

select p.item 1, p.item2, ..., p.itemk-1, q.itemk-1

from $L k-1 p, L k-1 q$

where p.item $1=q$. item $1, \ldots$, p.itemk-2=q.itemk-2, p.itemk-1 < q.itemk-1

Untuk nilai lift dari tiap penawaran yang diterima adalah $>1$ karena bila nilai lift $>1$ maka keterikatan barang tersebut dianggap kuat (Abrahams, 2004).

Setelah penawaran selesai maka akan muncul penawaran dalam bentuk tabel yang berisi kode barang, jumlah macam barang dalam pola kombinasi pembelian, jumlah macam barang dalam pola kombinasi penawaran barang, dan nilai supportnya. Tampilan tabel dalam penawaran barang adalah per lima barang dengan urutan nilai (berdasar pada nilai kombinasi beli, nilai kombinasi penawaran, dan support) descending. Jumlah barang yang ditawarkan akan 
bervariasi tergantung dari kombinasi barang yang dibeli. Pencarian penawaran akan berhenti bila terdapat lebih dari 20 barang dalam tabel penawaran. Perhitungan jumlah barang akan dilakukan pada akhir pencarian kombinasi pembelian. Pada form penawaran terdapat fasilitas mencetak penawaran barang. Cara untuk mencetak penawaran barang adalah terlebih dulu memilih kode barang dari list penawaran, kode barang yang ingin ditawarkan dipilih dengan meng-dobel klik kode dalam list penawaran, pada saat memilih barang yang ingin ditawarakan pada grid barang terkait akan muncul macam barang yang menjadi pola penawarannya (berelasi dengan barang yang terpilih) jika kombinasi dari barang yang dipilih lebih dari 1. Setelah semua barang yang ingin ditawarkan dipilih maka user dapat mengklik tombol cetak. Setelah tombol cetak ditekan, maka akan akan tampil form tampilan cetakan dan user dapat mencetak lembar penawaran dengan menekan tombol yang bergambar printer.

Pada penawaran terdapat fasilitas untuk melihat grafik (satu layar penuh) dari lima barang penawaran, cara untuk melihat grafik dari penawaran tersebut dengan men-dobel klik tulisan "grafik penawaran" yang terletak di bawah grid pertimbangan barang penawaran. Form tampilan grafik penawaran seperti pada gambar 5. Selain grafik penawaran, alur penawaran dari kombinasi penawaran dan kombinasi pembelian dan penawaran ditampung dalam sebuah treeview.

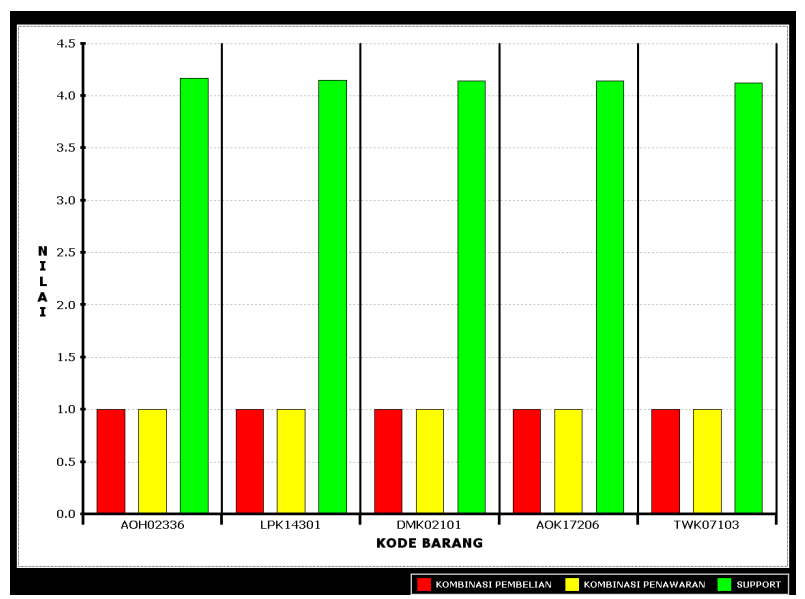

Gambar 5. Tampilan Grafik

Untuk melihat pada tabel transaksi yang dijadikan pertimbangan, transaksi apa saja yang mengandung pembelian yang ada pada transaksi dengan nomer nota yang akan dicari penawarannya dapat dilihat pada form transaksi pertimbangan.

\subsection{Kemampuan dan Kelemahan Sistem}

Adapun kemampuan dari sistem yang dibuat adalah sebagai berikut: (1) Analisis menggunakan metode Association Rule yang dioptimalkan dengan algoritma Apriori mampu melakukan analisis penawaran terhadap data yang besar dalam waktu yang singkat. (2) Penentuan nilai confidence dari tiap penawaran berdasar pola penjualan yang lampau. (3) Sistem mampu memberikan pertimbangan penawaran barang dengan metode market basket analysis. (4) Sistem dapat mencetak laporan penawaran barang tertentu yang dapat dipilih oleh user. (5) Sistem dapat memberikan tampilan grafik penawaran untuk tiap barang dalam pola penawaran yang ada. Sedangkan kelemahan sistem adalah untuk inputan batas nilai support dan confidence yang rendah membutuhkan waktu yang lama.

\subsection{Pengujian dengan Menggunakan Data Transaksi Penjualan}

\subsubsection{Preprosesing}


Data transaksi yang digunakan dalam proses ini harus diubah dulu menjadi bentuk flat tabel. Proses perubahan ini meliputi dua hal: (1) Proses penyalinan tabel dari visual foxpro menjadi SQL Server. (2) Proses perubahan relasional tabel menjadi flat tabel.

\subsubsection{Proses penawaran}

Setelah proses preprosessing selesai, proses penawaran dapat dilakukan. Proses penawaran tersebut menggunakan 3 sampel data transaksi. Transaksi penjualan tersebut dapat dilihat dari tabel 2 dan tabel 3.

Tabel 2. Transaksi penjualan

\begin{tabular}{ccc}
\hline No.Transaksi & Tanggal & No Konsumen \\
\hline 19345885 & $26 / 01 / 2005$ & KA0601805 \\
\hline 19345886 & $26 / 01 / 2005$ & KC6001138 \\
\hline 19345887 & $26 / 01 / 2005$ & KC 8499497 \\
\hline
\end{tabular}

Tabel 3. Transaksi penjualan barang

\begin{tabular}{ccc}
\hline No.Transaksi & Kode barang & Jumlah \\
\hline 19345885 & BMA29213 & 10 \\
\hline 19345885 & NMG06115 & 5 \\
\hline 19345885 & TWA07213 & 12 \\
\hline 19345885 & TWA07503 & 5 \\
\hline 19345885 & TWB01403 & 5 \\
\hline 19345886 & BMA29108 & 20 \\
\hline 19345886 & KKA22308 & 5 \\
\hline 19345886 & KKA22325 & 15 \\
\hline 19345886 & STA13303 & 5 \\
\hline 19345886 & TWB01402 & 10 \\
\hline 19345886 & TWB45301 & 5 \\
\hline 19345887 & MCB07303 & 15 \\
\hline 19345887 & MCB08303 & 5 \\
\hline 19345887 & MCB25316 & 10 \\
\hline
\end{tabular}

Nilai support dan confidence yang digunakan untuk masing-masing transaksi transaksi dapat dilihat dari tabel 4.

Tabel 4. Support dan confidence

\begin{tabular}{ccc}
\hline No.Transaksi & Support & Confidence \\
\hline 19345885 & $0,13 \%$ & $0,00 \%$ \\
\hline 19345886 & $0,00 \%$ & $47,98 \%$ \\
\hline 19345887 & $3,64 \%$ & $50,23 \%$ \\
\hline
\end{tabular}

Transaksi dengan nomer nota 19345885, membeli 5 macam barang. Nilai support sebesar 0,13 atau minimal support yang diterima adalah lebih besar dari 0,13\% dari transaksi penjualan atau sebesar 98 transaksi penjualan. Sedangkan nilai confidence nya adalah 0,00 atau batas nilai confidence yang diterima adalah lebih besar dari $0,00 \%$. Hasil yang didapat dari inputan ini adalah penawaran hingga memenuhi nilai support $>0,13$ dan nilai confidence $>0,00$ $\%$. Jumlah penawaran yang ada adalah 44 penawaran barang, yang terdiri dari kombinasi 2. 
Hasil output form penawaran tersebut dapat dilihat dari gambar 6 .

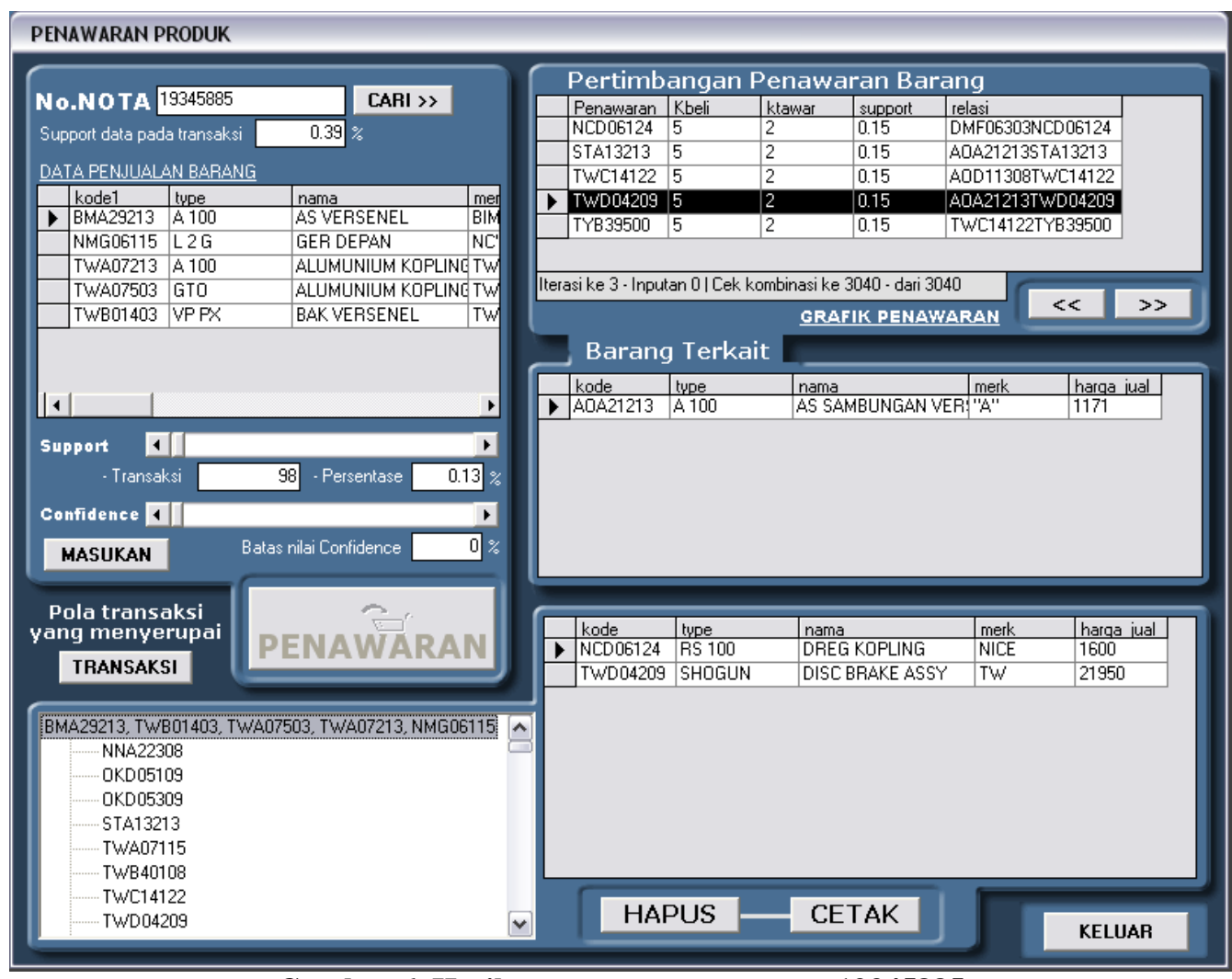

Gambar 6. Hasil penawaran nomer nota 19345885

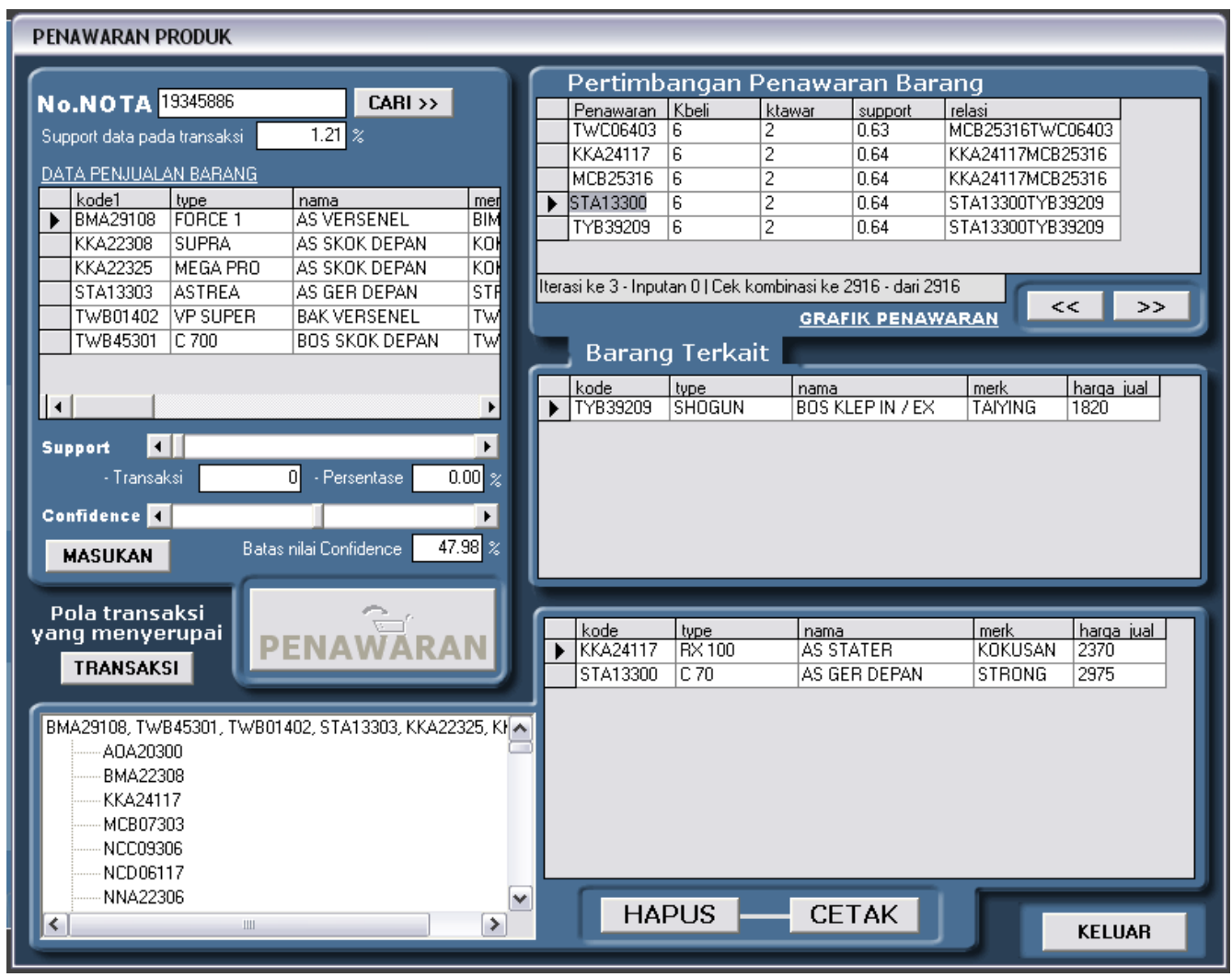

Gambar 7. Hasil penawaran nomer nota 19345886 
Transaksi dengan nomer nota 19345886, membeli 6 macam barang. Nilai support sebesar 0,00 atau minimal support yang diterima adalah lebih besar dari 0,00 \% dari transaksi penjualan atau sebesar 0 transaksi penjualan. Sedangkan nilai confidence nya adalah 47,98 atau batas nilai confidence yang diterima adalah lebih besar dari 47,98 \%. Hasil yang didapat dari inputan ini adalah penawaran hingga memenuhi nilai support $>0,00 \%$ dan nilai confidence $>$ $47,98 \%$. Jumlah penawaran yang ada adalah 34 penawaran, yang terdiri dari kombinasi 2 . Hasil output form penawaran tersebut dapat dilihat dari gambar 7 .

Transaksi dengan nomer nota 19345887, membeli 3 macam barang. Nilai support sebesar 3,64 atau minimal support yang diterima adalah lebih besar dari 3,64\% dari transaksi penjualan atau sebesar 2755 transaksi penjualan. Sedangkan nilai confidence nya adalah 50,23 atau batas nilai confidence yang diterima adalah lebih besar dari 50,23\%. Hasil yang didapat dari inputan ini adalah penawaran hingga memenuhi nilai support $>1,57 \%$ dan nilai confidence $>50,68 \%$. Jumlah penawaran yang ada adalah 27 penawaran, yang terdiri dari kombinasi 1 . Hasil output form penawaran tersebut dapat dilihat dari gambar 8 .

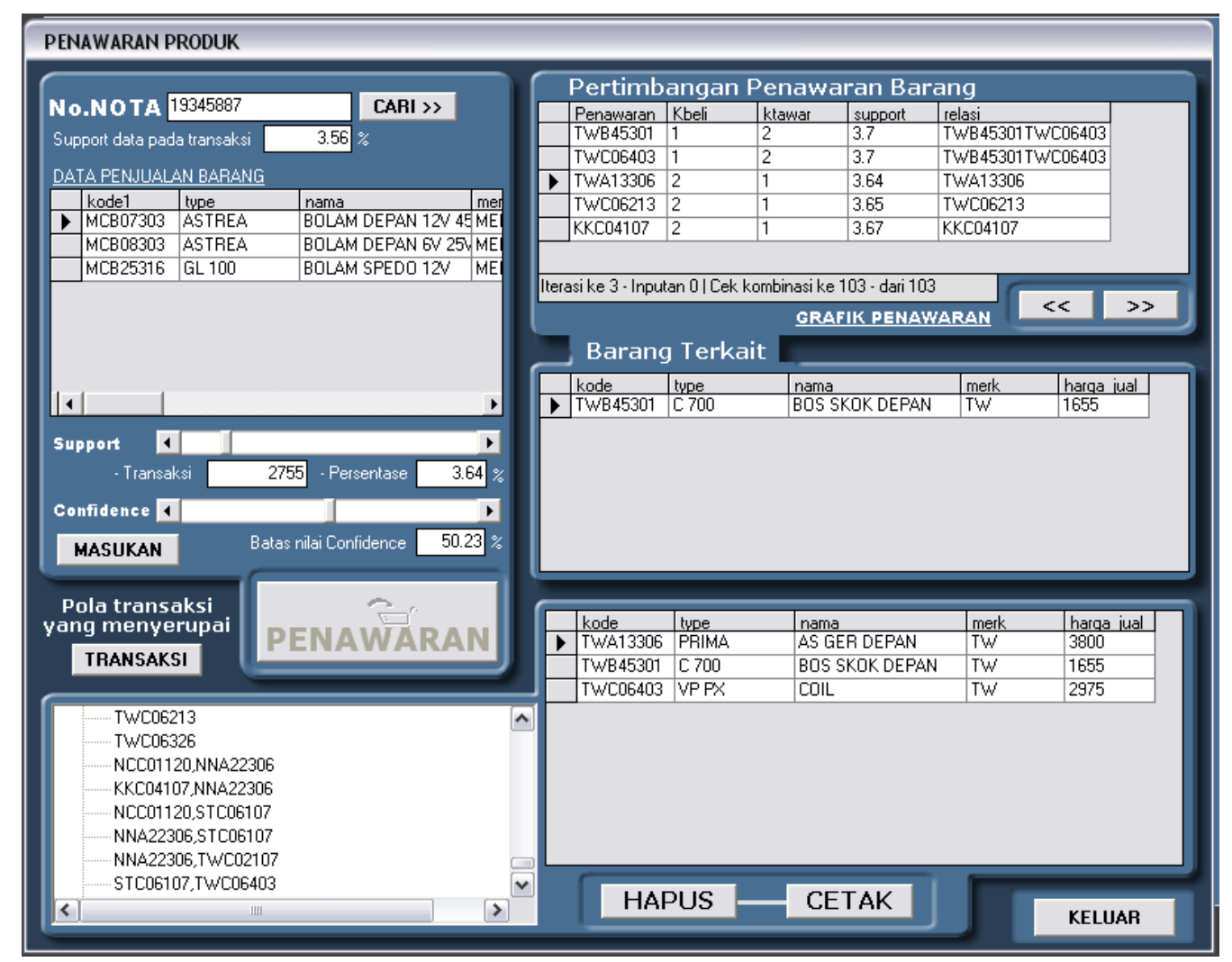

Gambar 8. Hasil penawaran nomer nota 19345887

\section{Kesimpulan}

Berdasarkan perancangan dan implementasi program, maka diperoleh kesimpulan sebagai berikut : (1) Hubungan relasional antar tiap produk yang dibeli secara bersamaan dapat dirumuskan menggunakan analisa Association. Selanjutnya hasil metode Market basket analysis digunakan sebagai penawaran kepada konsumen. (2) Proses penawaran barang dan transaksi penjualan tidak dapat digabungkan karena waktu yang dibutuhkan untuk mendapatkan penawaran barang dari 1 transaksi penjualan cukup lama. (3)Besarnya data pertimbangan akan membuat relasi di tiap barang semakin sedikit, dan besarnya macam penawaran barang akan mempengaruhi nilai confidence dari tiap barang. Semakin tinggi nilai confidence akan semakin kecil jumlah macam barang yang ditawarkan, dan sebaliknya. (4) Dengan pencarian pola relasi penjualan terlebih dulu sebelum melakukan penawaran, maka penawaran barang yang 
berpeluang kecil untuk terbeli akan terabaikan atau tidak ditawarkan. (5) Pertimbangan nilai support dan confidence akan mempunyai keterikatan yang sama, karena pembatasan nilai support suatu pola penawaran juga akan membatasi nilai confidence pola penawaran tersebut. User dapat hanya memilih salah satu inputan, support atau confidence dari penawaran.

\section{Saran}

(1) Program yang dibuat dengan algoritma Apriori akan memakan waktu yang cukup besar. Untuk pengembangan program dan mempersingkat waktu, algoritma Apriori dapat dikembangkan dengan dengan algoritma yang lain, seperti FP Tree, Partitioning, dan masih banyak lagi perkembangan algoritma Apriori untuk mempersingkat waktu. (2) Selain Algoritma, besar data pertimbangan dan barang akan mempengaruhi jumlah waktu yang dibutuhkan selama proses. Data pertimbangan yang digunakan dapat dikurangi atau dipotong dengan cara mencari transaksi yang memiliki nilai beli tinggi, atau hanya menggunakan periode waktu tertentu, misalnya 6 bulan. Pemotongan data pertimbangan akan mengurangi waktu proses analisa dan waktu preprosesing data yang cukup lama. Macam barang, pada data barang dapat dikurangi dengan cara mengontrol barang apa saja yang sebenarnya ingin ditawarkan. Jumlah data barang akan mempengaruhi proses pencarian kombinasi pola penawaran tersebut.

\section{Referensi}

Abrahams, Alan. 2004. Decision Support Systems - Association Rules. University of Cambridge Computer Laboratory \& The Wharton School Room 555 http://www.cl.cam.ac.uk/ asa28/opim410; 7 Mei

Han Jiawei dan Micheline Kambar. 2000, Data Mining : Concepts and Techniques. Morgan Kaufmann, San Fransisco.

Kantardzic Mehmed. 2003, Data Mining Concepts, Models, Methods, and Algorithms. United States: John Wiley \& Sons, Inc.

Marakas M. George. Modern Data Warehousing, Mining, And Visualization. New Jersey: Prentice Hall, 2003

McCarthy E. Jerome. 1982, Essentials of Marketing. Michigan, Richard D. Irwin, Inc.

McDaniel Carl, 1987, JR dan William R, Darden. Marketing. Massachusetts, Allyn and Bacon, Inc.,

Mei-Ling Shyu dan Choochart Haruechaiyasak. 2003, "Mining Association Rules with Uncertain Item Relationships." Coral Gables, Miami: Department of Electrical and Computer Engineering, University of Miami, FL 33124; dalam http://www.cs.fiu.edu/ chens/PDF/ SCI02.pdf; 18 November

Redlon Matthew. 2004, Paper 223-28 : A SAS Market Basket Analysis Macro: The "Poor Man's Recommendation Engine”. dalam http://www2.sas.com/proceedings/sugi28/ 22328.pdf; 7 Juni.

Sander Jorg. 2004, Principles of Knowledge Discovery in Data - Association Rules. dalam http://www.cs.ualberta.ca/ joerg/courses/cmput695/winter2003/AssociationRules4spp.pdf; 3 November. 